International Journal of Islamic Educational Psychology

Vol. 1, No. 2, December 2020

DOI: https://doi.org/10.18196/ijiep.v1i2.9739

\title{
Self-Regulatory Learning Patterns of Disabled Students at UIN Sunan Kalijaga Yogyakarta
}

\author{
1Zamakhsari*, ${ }^{1}$ Siswanto Masruri, 1 Sutrisno \\ ${ }^{1}$ Universitas Islam Negeri Sunan Kalijaga Yogyakarta, Indonesia \\ *Corresponding email: zamakhsari@gmail.com
}

\section{ARTICLE INFO}

Article history

Received, 05/09/2020

Revised, $12 / 10 / 2020$

Accepted, 19/12/2020

\section{Keywords}

Self Regulation

The disabled

Learning Pattern

Metacognitive

Knowledge

\begin{abstract}
This study aims to find the learning patterns of students with visual disabilities through self-regulation. This research approach is qualitative with phenomenological design and descriptive methods. This research study is a self-regulation pattern in students with visual disabilities by observing the interaction between students and the learning environment and social environments to achieve individual and academic goals. The author collected the data through interviews, observations, and documentation. This study concludes that this informants' metacognitive contribution provided positive and supportive directions for learning patterns based on students' selfregulation with visual disabilities UIN Sunan Kalijaga Yogyakarta. The self-regulation of informants in learning formed from this metacognitive knowledge relied on the sense of hearing. The strategy came from listening, taking, and reading notes.
\end{abstract}

This is an open access article under the CC-BY-SA license.

\section{Citation:}

Zamakhsari, Z., Masruri, S., \& Sutrisno, S. (2020). Self-Regulatory Learning Patterns of Disabled Students at UIN Sunan Kalijaga Yogyakarta. International Journal of Islamic Educational Psychology, 1(2), 126-146. DOI: https://doi.org/10.18196/ijiep.v1i2.9739 
Zamakhsari, Masruri \& Sutrisno | Self-Regulatory Learning Patterns of Disabled Students at UIN Sunan Kalijaga Yogyakarta

\section{INTRODUCTION}

Universitas Islam Negeri (UIN) Sunan Kalijaga Yogyakarta is one of the universities which includes many disabled students and has provided a disabled service unit. No less than 27 students with visual impairments are currently studying at various faculties of this university. So far, there is no special treatment for them when undergoing lectures - their treatment when learning is the same as those of non-disabled students (Hanjarwati, A., \& Suprihatiningrum, J. 2020). Sometimes there are differences because of differences in the lecturers' service to them. Institutionally, the university has not issued official regulations regarding university services for students with disabilities.

The possibility to answer the phenomenon above is through students with visual disabilities towards the religion they profess (Hanjarwati, A., \& Suprihatiningrum, J. 2020). All students with visual disabilities who study at UIN Sunan Kalijaga are Muslims. In Islam, pursuing knowledge is obligatory and is carried out throughout the ages, regardless of gender and physical perfection (Azizah, N., \& Rahmatika, A. (019). According to Islamic law, adulthood is considered capable of being burdened with an obligation (mukallaf). Demanding the knowledge they do can be interpreted as an effort to enforce these obligations. Another factor causing them to be enthusiastic about learning and graduate is that the education obtained previously has supported them in self-adjustment. It includes self-help (ability to help oneself), self-support (ability to motivate yourself), self-concept, self-care, and self-orientation (Mohamad Efendi, 2009).

There is a positive relationship between capacity attainment and students' ability to organize themselves. As a student, the learning capacity comes from listening to lectures, taking notes during studies, and learning from lecture notes. Management of learning capacity comes from a combination of motivation to achieve success with the environment's demands - the control of these students' learning capacity management (Rinawati, R., Lestari, E. S., \& Narendra, A. P. 2017). The condition of students with visual disabilities is limited compared to other regular students. The preliminary findings' reality found that they want to achieve the hope of success in learning (Andayani, A., \& Afandi, M. 2019). All their efforts are impressive to research a challenging environment that requires anticipatory action. Based on the background of the problems described, the authors are interested in investigating "How is the pattern of self-regulation in teaching students with visual disabilities UIN Sunan Kalijaga Yogyakarta."

\section{LITERATURE OF THE DISABLED STUDENTS LEARNING REVIEW}

The notion of learning also emphasizes the process or activity of obtaining a result. Studying is an activity to acquire knowledge, improve skills, improve behavior, attitudes, and strengthen personality (Suyono and Hariyanto, 2012). There are many opinions in learning theory, both classical and modern. The 
existing learning theories can positively complement each other to integrate and give birth to new approaches. The broader aspects of learning theory, not just processes and outcomes, are described in learning theories as summarized (Eti Nurhayati, 2011). Slametto defines the concept of learning following the behavioristic flow. There is a change in behavior characterized by the following characteristics: (1) occurring consciously; (2) continuous and functional; (3) positive and active; (4) permanent; (5) aimed and directed; (6) covering all aspects of behavior (Slametto, 1995).

Students are people who study in college. Another definition states that students are individuals who go to college regularly and do not work. Students are individuals who are in early adulthood. Early adulthood is the transition from adolescence to adulthood. The average age of students starting to graduate from high school is 18 years old. The student's obligation to complete college is a maximum of 7 years ( 14 semesters), then the student's age is up to 25 years. Thus, the age of undergraduate (S-1) students, in general, is 18-25 years.

Individuals in early adulthood experience developments such as autonomy from parents, show clear sex rules, internalized morals, indicate the direction of career choices, try various regulations, and a clash of self-identities occurs (Eti Nurhayati. 48). Students' obligation to organize their learning to finish on time creates problems, especially if they are less independent and find it challenging to make the best decisions for him. Learning on students has different characteristics from learning on students. Learning for students demands a high degree of independence. With the semester credit unit system, students can plan their studies, implement them, and evaluate their success. Students should have learning skills at all the learning stages above.

At the average age of normal children, the development of communication skills has experienced various improvements. The capacity for social interaction skills is fundamental to recognizing other people's sentiments and maintaining extensive friend connections, especially in the early education years. However, when the capacity of discourse and language does not give the impression of being pleasantly developed, it can interfere with the actual communication process, without a momentary delay affecting the ability of newborns to form friends and regulate emotions in several other characters (Fadilah, 2020, Khaidir et.,al., 2020).

The discussion about the learning process leads to the term andragogy (Malcolm Knowles; 2017). There are five assumptions built into andragogy-first Selfconcept. Adults have grown and experienced the process of learning from a variety of things. Within him, there were concepts about how he acquired knowledge. The adult personality is relatively stable and does not depend entirely on others in directing his life. Second, Experience-someone's experience has been the best teacher for him because adults have had many adventures. Experiences are valuable lessons for moving forward. 
Third-Readiness to learn requires the adults to fulfill their functions as individuals and society members due to age maturity. Thus, the tasks need them to do learning. Fourth-Orientation to learn, adult learning is oriented more towards practical goals than content. Learning is more about solving a problem than a general issue. Adult learning is towards the tasks of his social development and is a problem-centered orientation. Learning assignments that are right for them are tasks related to solving everyday life problems, not subjectcentered orientation.

Fifth, Motivation to learn-Adults in learning motivation depart from within themselves. With metacognition, a person will control what should be done, understand the consequences of doing and not, understand the benefits, be ready to accept failure if he does, etc. The ability to exercise control above is because a person has knowledge or awareness of the process of thinking about himself. People with good metacognition can realize whether they have mastered it or not and their level of mastery.

\section{SELF-REGULATION PATTERN}

The theory that underlies self-regulation in learning is the social cognitive learning theory of learning. Zimmerman introduced self-regulation in learning. Self-regulation is important because education's primary function is developing lifelong learning skills (Barry J. Zimmerman, 2002). Lifelong learning (long-life education) is relevant to the spirit of Islam. There is a word of wisdom, "seek knowledge from the cradle to the grave." A person who has graduated from high school acts like an adult who is expected to learn essential skills informally.

Bandura defines self-regulated learning as a situation where students determine their learning, monitor academic goals, and motivate themselves, manage learning materials, take decisions and actions in all learning processes. Thus, selfregulation in learning occurs in students (internally) doing a thought process by utilizing the environment to manage both together to achieve effective learning. (Mi-Kyung Chung, 2000).

Students, including students with visual impairment, are required to be independent. According to Schunk and Zimmerman (Arini Dwi Alfiana, 2013), this independence is a learning process that demands students' capacity to regulate themselves while participating in the learning process. Alsa in Alfiana explains that effective learning is learning based on self-regulation. A person with low self-regulation will negatively impact. As Martinez \& Weinstein explained in Alfiana, he feels frustrated as he cannot do assignments, being uncomfortable in a job due to inappropriate feelings, and fail to achieve optimal performance.

Islam strongly underlines the need for motivation in acting, including in learning, 
because with the right motivation and according to Islamic teachings, these actions are interpreted as worship. (Muhammad Izzuddin Taufiq, 2006). Those influence a person's motivation to achieve something, both external and internal, both extrinsic and intrinsic, as the saying of Prophet Muhammad PBUH: "The reward of deeds depends upon the intentions, and every person will get the reward according to what he has intended" (Narrated by Bukhari).

Motivation in adults is following their self-concept as independent individuals. The self-maturity development of adults today can lead to self-determination and self-direction. Student motivation in independent learning is called engagement, which guides students to have free responsibility to learn by using various strategies. The motivation for independent learning can be obtained from peer imitation, goal setting, and feedback (Robert E. Slavin, 2008).

Bandura is seen as the expert who first introduced the concept of self-efficacy in his Social Cognitive Theory. Bandura states that (Bandura, 1977), self-efficacy is a person's belief in one's ability to succeed in various unique situations). According to Bandura, activities carried out by a person are due to internal or external factors but are a harmonious collaboration between the two. What acts as a regulator is self-efficacy, which at the same time influences one's thinking and behavior.

\section{Metacognitive}

Metacognition comes from the English word. Meta is a prefix in English, showing a concept that is an abstraction from another concept. Furthermore, in Wikipedia, the notion of metacognition in a language is a mental process that involves attention, memory, producing and understanding language, thinking, problemsolving, and making decisions about a concept in an existing concept.

Students who learn based on self-regulation are proactive in their efforts to learn because they know their strengths and weaknesses and are guided by goals and strategies related to their assignments. These students monitor their behavior in terms of their goals and reflect on their increasing effectiveness. It increases selfsatisfaction and motivation to improve learning methods continually. Due to their high motivation and adaptive learning methods, students who have selfregulation have the chance to succeed academically and view their future optimistically.

\section{Learning Strategy}

Strategies are cognitive tools that help students construct understanding, and different cognitive tasks require different tools. A learning strategy is a cognitive plan that is oriented towards the success of the task. For example, when solving a problem requires solving through applying concepts, procedural knowledge is very appropriate to be chosen, not just declarative knowledge. In language learning, it is hoped that students can compile prose (Wahyuna, A. H., \& Fitriana, S. 2020). What is needed is understanding prose and prose structure (declarative 
Zamakhsari, Masruri \& Sutrisno | Self-Regulatory Learning Patterns of Disabled Students at UIN Sunan Kalijaga Yogyakarta

knowledge); and techniques of composing prose through the direct practice of composing prose (procedural knowledge) - understanding and monitoring.

\section{Self-Regulation Patterns in Learning}

The definition of patterns from the Indonesian Dictionary is the image used, the style, the system, the way of working. (Center for Language of the Ministry of National Education, 1997) A self-regulation pattern is a model that describes the components of self-regulation in learning that together explain the occurrence of self-regulation in learning. Chung describes 3 (three) patterns of self-regulation in learning, which are the results of research by experts:

\section{Model I}

It is based on Biggs Learning Process Model and McCombs's Unified Model because the motivation variable is exogenous (exogenous intrinsic learning). This model assumes a variable that affects academic achievement, but indirectly is a variable between metacognition and learning strategies.

Model II

Model II is based on Pintrich and De Groot's research, and the model proposed by Garcia and Pintrich using covariance analysis. Model II states that motivational variables such as self-efficacy, intrinsic value, and anxiety do not directly predict academic achievement but indirectly affect academic achievement through metacognition and learning strategies.

Model III

Model III is based on research by Ames and Archer, Meece, Wiffield and Eccles, and Miller, Behrens, and Greene. Self-efficacy is assumed to be an exogenous variable that affects academic achievement, metacognition, learning strategies, intrinsic value, and anxiety. Intrinsic value and anxiety are assumed to be intermediate variables on metacognition and learning strategies.

The need for student achievement has indicators of 1) Having a plan or goal for the future. 2) Doing his job for personal satisfaction and not a reward. Taking responsibility for students means 1 ) doing their job maximally 2) not delaying the assignment assigned to them. Self-motivation is a component of self-regulation in learning in addition to behavior and metacognition. In line with this, Zimmerman \& Bandura state that (Bandura 1992) this conceptual model describes the relationship between self-regulatory motivation and learning. Self-regulatory efficacy affects self-efficacy on academic achievement, individual goals, and the level of achievement achieved. Self-efficacy is the confidence to solve a particular problem and influence how to solve the problem. These relationships are presented in the following chart. 


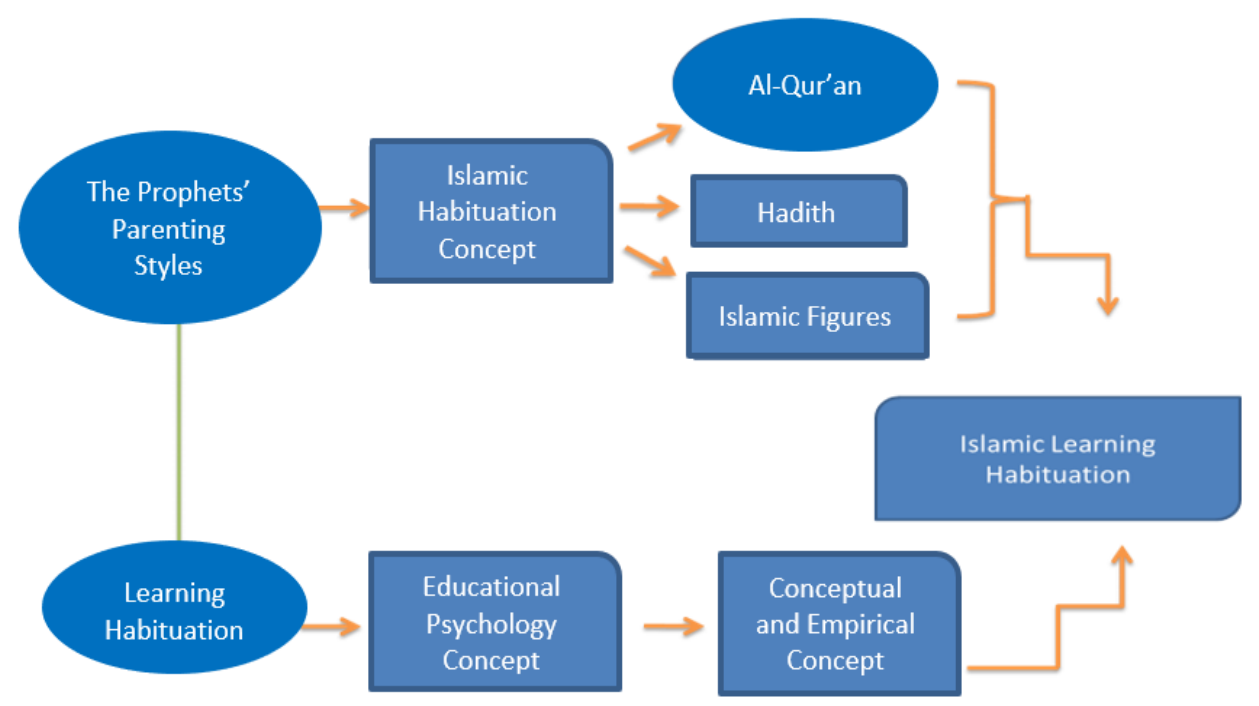

Chart 1.1 Relationship Model in Student Self-Motivation

\section{METHODS}

This research approach was a qualitative approach with a phenomenological design and descriptive methods. This research material objectified students with visual impairment at UIN Sunan Kalijaga Yogyakarta in the 5th semester. The research data were formal objects obtained non-experimentally, namely the data collected according to the researchers' observations and not given any treatment. The data were about self-regulation in learning for students with visual impairment. In this study, there were 3 data collection methods (interviews, observation, and documentation), so that coding administration was needed about methods, sources, and research focus.

\section{RESULTS AND DISCUSSION}

\section{Knowledge of Cognition}

Knowledge of cognition under study is the ability to understand the strengths and weaknesses of the informant. The authors are aware that this ability is essential to have. The condition of the informants who want them to accept it is not easy to do. They should have a deeper understanding of themselves so that their potential can develop optimally and provide a better life for them. In addition to their obvious limitations, namely their lack of vision, they certainly have advantages that informants sometimes do not realize (Basuki, U., \& Jaelani, A. Q. 2015). Realizing their strengths will increase their motivation to act, socialize, and especially in lecture activities. The self that is aware of a weakness in terms of not seeing is a self-acknowledgment that should be owned. However, that does not 
Zamakhsari, Masruri \& Sutrisno | Self-Regulatory Learning Patterns of Disabled Students at UIN Sunan Kalijaga Yogyakarta

mean they will be weak in every way. The only weakness is in the sense of sight. For other matters, they may be superior to alert students. Knowledge of cognition includes: (1) being aware of one's weaknesses, (2) the informants' preferences, (3) knowledge/skills required in lectures, (4) the purpose of attending lectures, and (5) tasks of interest.

\section{Recognizing Self Weaknesses}

A reduction was made to each informant's interview. It aimed to make it easier to analyze their self weakness awareness. The interview results with informant 1 showed that he thought that his parents were ashamed of him being blind, and the school where he went to (special school) fit his condition.

Informant 2 implied that he was not good at Math and not fond of statistics. He also had excessive excitement for everything. The interview results of informant 3 showed that many people did not care about him. His handwriting was awful, and he had limited reading the Qur'an ability. He also wanted to have a lot of achievements as their friends without visual impairment. The interview results of informant 4 indicated that he had difficulties in reading Braille at school and was aware of being different from other students. Informant 5 reported that he could not write the Arabic script well and memorize hadith.

Meanwhile, informant 6 implied that he had difficulty in writing Braille quickly. He admitted that he was not a tech-savvy person. Courses that included Arabic writing, Math, and statistics were difficult for informant 6 . Informant 7 also had quite similar issues that he had difficulties in statistics, writing Arabic and English, and reading Qur'an. Therefore, he lacked self-confidence. The data showed the informants' weaknesses clearly. The weaknesses of each informant vary widely, but they could be simplified into three groups. They are (1) physical deficiencies; (2) lack of ability in certain subjects; (3) and awareness of selflimitation.

\section{Feelings of Physical Inadequacy}

The informants' awareness of vision deficiencies is manifested in the following feelings: 1) Feeling that their parents are ashamed of sending them to school because they are blind. 2) Feeling that special schools are suitable for those who are blind. 3) Feeling that many people do not care. 4) Feeling insecure. Four informants had a different awareness of physical weakness compared to those normal ones. This awareness can be good or bad. As a place that suits one's condition, the informants realized that special schools formed self-readiness to accept deficiencies. Self-readiness is what the informants must prepare to receive lessons and habituation (Suud et al., 2019). With the feeling that their parents were ashamed of their condition, the informants felt that parents who should protect and encourage them for their shortcomings became devastated. The informants felt that parental treatments that did not match expectations made it difficult for them to develop themselves because of unprotected inferiority from the closest 
Zamakhsari, Masruri \& Sutrisno | Self-Regulatory Learning Patterns of Disabled Students at UIN Sunan Kalijaga Yogyakarta

ones.

The feeling of being ignored by others should be redemption to pay more attention to them as they might not get enough. Their level of sensitivity is high to the unfavorable treatment against them. Hence, their feelings are subtle because of their disabilities.

1) Inability in certain subjects, such as Mathematics and statistics, is a dominant self-acknowledgment.

Mathematics and statistics use complicated formulas to describe without looking directly. Therefore, the informants may consider them difficult. Braille difficulty ranks second in the problem of informants' incapacity. Although the number of books written in Braille is not large, the ability to read and write in Braille is essential for informants. It is an input for educational institutions with visual impairments at the primary and secondary levels to improve learning methods for mastery of Braille's reading and writing competencies. In higher education, in this case, UIN Sunan Kalijaga Yogyakarta, specifically for students with visual impairments, a place and time is provided to improve and deepen their reading and writing skills in Braille. Communication forums between students with visual disabilities can be used in the form of sharing this ability.

2) Self-Limits Awareness

This awareness is positive, including overzealousness, awareness of having awful handwriting, not having a similar ability as other students without visual impairment, always wanting to excel, not minding the blindness, and realizing the differences (Suud, 2018). By realizing their limitations, informants do not feel discouraged when they fail to achieve a target. In the observation, some informants showed high self-confidence with their limitations.

Even observations of discussion activities in class, some informants showed extraordinary contributions by providing views on a problem being discussed. The informants tried to give their best contribution to the discussion by conveying their views on a case and solving the problem. Thus, the informants were indeed aware of their weaknesses and did not feel bothered. They were even motivated to look superior, especially in classroom activities. It is input for the lecturers to provide students with visual impairments to take an active role or provide assignments that require them to make an active contribution and show their existence.

\section{Knowledge and Skills Required in Class}

Each informant has the skills needed in the classroom to achieve success in the university. Informant 1 provided a brief description such as looking for lecture materials using the internet, reading Al-Qur'an (Khafidah et al., 2020), having the ability to write Braille, and transfer lecture material into a written summary. 
Informant 2 gave described being sociable and recognizing the nature of others. Informant 3 showed a willingness to read, including the ability to read and write Al-Quran and hadith. Informant 4 gave a brief description, namely, social science, counseling, and research.

Informant 5 implied the ability to read Al-Qur'an, have English proficiency, listen to lectures, make an accurate and concise summary, and talk to other people. Informant 6 provided a brief description, such as being sociable, speaking, understanding the general theory and theory in Islam (Baidarus et al., 2020) and applying knowledge in practice. Informant 7 noted reading Al-Qur'an and understanding its meaning, counseling, being sociable, and helping people in need. The abilities required in lectures can be classified into social skills and their application, academic ability, and supporting capabilities.

1) Social Ability and the Application.

Four informants or $57.14 \%$ conveyed the importance of social skills and their applications, including being sociable, recognizing others' nature, speaking ability, and helping people in need. Awareness of having these abilities are necessary so that informants can organize and control themselves to have an excellent social attitude as students and part of society in general.

2) Academic Ability

Academic ability is directly related to the need for attaining lecture competencies. The academic abilities identified through interviews include reading and understanding meanings of the Qur'an, mastering social science, counseling, research, English ability, understanding general theory and theory in Islam, and the ability to practice knowledge. Six informants or $85.71 \%$ conveyed the importance of cognitive abilities related to the abilities required in the classroom.

3) Supporting Ability

Supporting abilities are not directly related to lectures but are needed to provide informants' convenience in classroom activities. Supporting abilities obtained from interviews with informants include internet searching, writing Braille, writing summaries, reading, and listening to lectures. Three informants or $42.86 \%$ stated that the supporting abilities above contributed to the knowledge of cognition required. The lecturers should understand that students with visual impairment have advantages in mastering the knowledge/skills required in the classroom. The informants should be allowed to optimize these abilities to support the success of lectures.

4) Purpose of Attending Classes

The data distribution of informants attending classes was obtained through data reduction. The interview method shows that noble goals are not merely to make them happy, such as the interview description 
following lectures expressed by informant 1 only to make his parents happy. Informant 2 and 3 gave a similar opinion. They attended classes so they could be independent and gain knowledge. Informant 4 and 5 wanted to graduate, live independently, and make both parents happy. Also, informant 5 added that he wanted to be a good teacher.

There are four purposes of attending classes, according to the informants. They wanted to make their parents happy, be independent, gain knowledge, and be good teachers. Making their parents happy and being independent are the four informants' purposes while gaining knowledge is the goal of two informants. Only one informant mentioned his aspirations to become a teacher explicitly.

\section{Self-Motivation Beliefs}

1) Independence in Classroom Learning Informant independence is classified into independent learning in class, doing assignments/exams, and outside class. Based on reduced data from interviews, the distribution of independent learning data for informant 1 was studying independently in class and did not depend on friends. Informant 2 determined activities freely during lectures. Informant 3 was independent when he is in the class. Informant 7 tried to memorize terms but did not have a laptop to listen to files.

Four informants or $57.14 \%$ of the data distribution of learning independence explicitly showed studying independently. Furthermore, the data were confirmed that all informants were independent in the classroom. Not a single informant was assisted by other students when heading to their chair. When the researchers asked one of the abled students, he had offered the informant help to the chair before, but the informant refused gently. Even when studying, the informant showed high independence, and he occasionally noted down lecturers 'explanations and friends' responses. The informants' faces did not show anxiety when learning. It proved that they had a sufficient level of selfconfidence in their ability to learn.

2) Independence in Doing Exams/Assignments

The independence of each informant, which is a reduction from the interview data regarding how they do assignments/exams, was answered by informant 1 . Informant 2 said that he was independent during the exam and did not rely on friends. Similarly, informant 4 independently worked on assignments, and informant 5 independently refused help from friends subtly. Informant 6 independently did the tests without cheating. 5 (five) out of 7 (seven) informants or $71.43 \%$ expressed themselves explicitly through interviews. When the researchers made observations of lecture activities, the informants also showed independent behavior in a discussion. They responded to task completion by providing views and 
reviews of the problem. They looked serious and active.

Furthermore, when the informants took the final exam, they also answered independently. Those who wrote the answers were volunteers, following the answers given verbally by the informants. Volunteers did not change the answers and sentence constructions. After completing one question number, the volunteers read the response back. If there were still additions, the informant would immediately submit and write it down by volunteers.

3) Independence Outside Classroom

The independence of the participants outside the classroom is also remarkable. The informants do not seem to need others' help. As researchers experienced when picking up an informant from his boarding house, he was invited to campus for an interview. He did not need help getting in and out of the car. The researcher only guided the informant to the door. Then he would walk by himself. All informants were severe about being independent. Six informants proved that they could live independently in the boarding house without their parents. Only one informant commutes every day as he lives near campus.

Meanwhile, the informants' independence outside the classroom is shown by going to specific locations, such as libraries, lecture halls, toilets, canteens, CDSS (Center for Disability Studies and Services) room, etc. on campus without assistance. In the orientation period, they also had been guided by volunteers. The implication for campus services for students with visual disabilities is clear and precise by involving competent instructors and volunteers to help them be independent. Besides, wellorganized access for people with visual impairments is an important point that makes it easier for informants to be independent around campus.

\section{Disabled Students' Efforts}

The efforts made by the informants are classified into four categories. They utilize information and communication technology, manage the time, show their abilities, and do other endeavors (Eka Mahendra, I. W. 2020). The effort to use information and communication technology by informant 1 was to gain information for lectures and assignments purposes and call friends. Informant 2 used files from lecturers and friends and read on a laptop. Informant 3, 4, and 5 browsed the internet for information, asking for files and reading them on a laptop. Informant 6 listen to the files with friends. Informant 7 typed on the rental computer (before having a computer), asked for help to correct it, arranged the layout, and then printed it out.

1) Utilizing Information and Communication Technology

The ability to use information and communication technology (ICT) is not only possessed by abled students. Technology that is open to everyone 
provides features/programs tailored to the conditions and circumstances of consumers. Based on the researchers' observations, the informants could use information and communication technology in classroom activities with different ability levels. In the table above, 5 informants have good abilities in using the Internet to search for lecture materials. There are 2 informants who have not been able to use them well but are still trying. Informant 6 , even though he does not have a laptop, tries to listen to files with friends. Informant 7 has a laptop but continues to learn with friends to be maximally utilized. Thus, the lecturers should not hesitate to apply ICT to provide materials and assignments. The use of ICT is easy for informants and has become their favorite section. There are 3 (three) informants who like to find information via the Internet.

2) Managing Time

The informants could manage their time well. An informant was an activist outside campus, but he could manage his time to not interfere with lecture activities. The informant would prioritize his study because he had a high commitment to succeed. Based on active informants' document data outside campus, their achievements are quite encouraging, with an achievement index of more than 3 . The informants still had time to do activities outside the campus to participate in a visual impairment organization and even occupy the management structure.

The researchers also received information that one informant played futsal. It is impressive, as well as touching. He has been using his time for various purposes, including physical exercise and strengthening their brotherhood. Besides, he held a particular recitation for the students with visual impairments and invited the researchers. He happened to be the manager of a visual impairment organization at the district level.

3) Showing Abilities

In showing their abilities, students with visual impairments keep it low. For example, one informant, who at madrasah aliyah was quite good at vocals and qira'ah, did not develop in the classroom. The lack of access showed that in public or campus organizations engaged in art activities, they did not assess students with disabilities. However, they consider students with disabilities as young adults who always want to show their existence. Informants still show abilities in front of their friends or others. One informant conveyed thoughts and insights on contextual problems to be solved in a discussion, showing his friends and lecturers' abilities. One of the informants who once could see wrote several sentences at his internship on the blackboard. Even though his writing was not appealing, the informant received a high appreciation for his hard work. It becomes an effort to show that people with visual impairment can do beyond what others think. 
Zamakhsari, Masruri \& Sutrisno | Self-Regulatory Learning Patterns of Disabled Students at UIN Sunan Kalijaga Yogyakarta

4) Doing Other Endeavors

The reductions in each informant's other efforts consist of 1) Asking friends about assignment problems the next day; 2) Taking simple notes; 3) Always trying to be steady. Interview with informant 2 was about learning from notes using Braille. Interview with informant 4 included completing the obligated tasks. Interview with informant 5 was 1) Learning Braille thoroughly; 2) Taking notes using Braille; 3) Studying in class and dormitories; 4) Always participating in class actively. 5) Learning by listening to information from friends; 5) Borrowing books from campus libraries and off-campus; 7) Recording his talk, then listening to it at home. Interviews with informant 6 involved 1) Recording important information and memorizing; 2) Listening to the explanation of the Qur'an in Arabic because there is no Arabic Braille. Interviews with informant 7 included 1) Asking a friend to read the lecturers' writings; 2) Writing the notes in Braille; 3) Repeating the material at home using the notes made.

\section{The Belief in Success}

The belief in success is part of the self-efficacy of cognition knowledge (Di Blas, L., Grassi, M., Carnaghi, A., Ferrante, D., \& Calarco, D. (2017). Informants need to achieve success. The following is a summary of the data on each informant's success, which is a reduction from the interview data. Informant 1 said that he believed in the power of God. He would succeed with hard work. Informant 2 believed that he would be successful and was confident. Therefore, he became a visual impairment organization manager. Informant 3 said that success would come if you meant it and always prayed. Informant 4 was sure to succeed in college. He further explained that past failures did not mean a permanent failure as he once had to repeat high school. Informant 5 was confident that being optimistic would bring success.

Most informants (5 out of 7 informants) or $71.43 \%$ were sure that they had achieved success even though one of the informants had experienced a failure. They were optimistic that they would achieve success with Allah SWT by working hard and feeling confident. Two informants did not explicitly express their belief in success. The informants' success beliefs are described in the following diagram. 


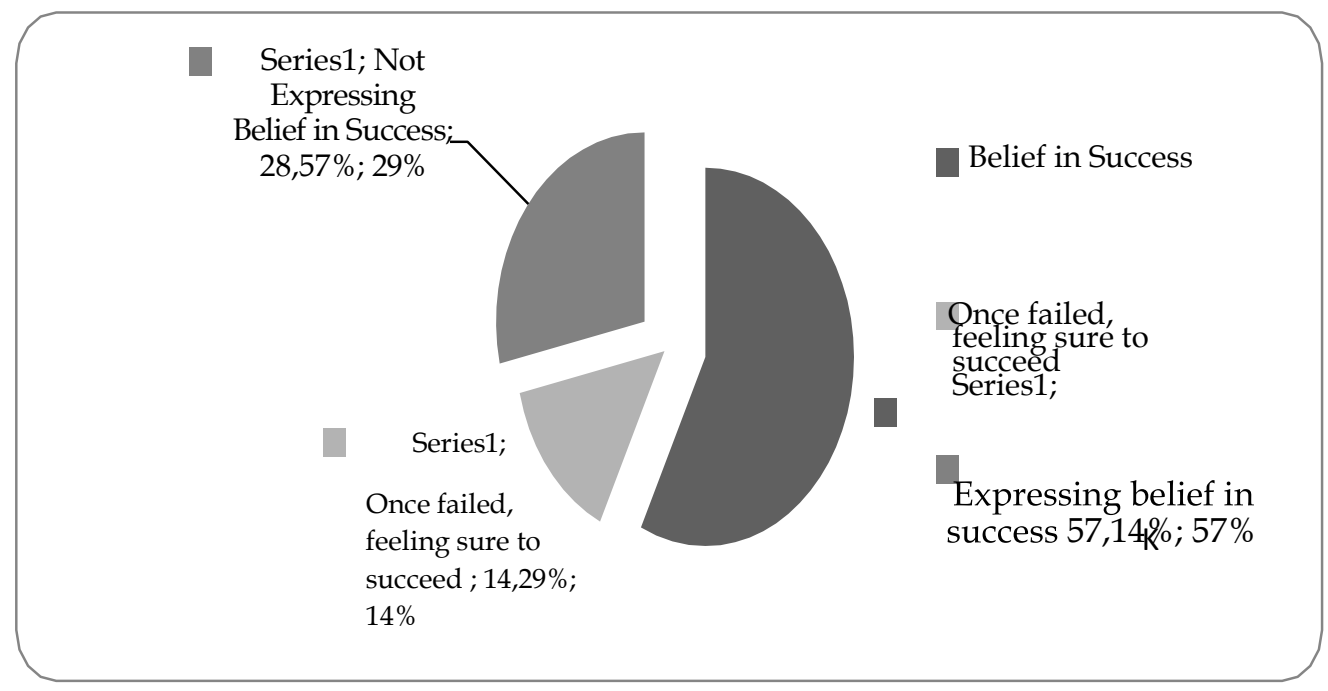

Chart 4. Distribution of the Belief in Success

Beliefs about goals are beliefs about the purpose/reasons the informants have for doing a particular task. The informants were students, so the tasks studied were their obligation as students and society. The informants' tasks can be grouped into 2 (two) major groups. They are lecture activities and non-lecture activities.

\section{Self-Regulation of Disabled Students with Neutral Metacognitive Components Declarative Knowledge}

The informants' declarative knowledge about their needs as learners includes strategies, skills, and learning resources. By having good declarative knowledge about what can help them study better, informants will achieve good learning outcomes (Berkeley, S., \& Larsen, A. 2018). This declarative knowledge is essential for the informants to recognize their abilities and use them in everyday life. According to the informants, students with visual impairments use various learning strategies in the classroom, campus, and off-campus. When in the classroom, informants rely heavily on their sense of hearing and then taking notes in Braille. Furthermore, when studying around campus, the six informants made efforts with the community to gather at the Center for Disability Studies and Services (CDSS) to get and listen to files with the JAWS Program through headphones.

According to their circumstances, there are classifications of learning strategies used by informants, as listed in Appendix 60, namely utilizing ICT, making notes/summaries, utilizing libraries, reading Braille, recording lectures with cellphones, and relying on memory. The learning strategies adopted by the informants are listening, taking notes, and repeating reading notes. Listening can be in the form of information from lecturers, friends, or files. The information can be downloaded from the internet or come from lecturers, friends, files in the center for disability studies (PSLD), and recording files by the informants. The files are listened to from laptops and cellphones using laptops or cellphones with JAWS. JAWS is a program that informants can use. The center for disability 
Zamakhsari, Masruri \& Sutrisno | Self-Regulatory Learning Patterns of Disabled Students at UIN Sunan Kalijaga Yogyakarta

studies has been delivering learning success by providing accessible and helpful program services for the informants to follow science and technology development.

The two informants explained that they browsed the internet to gain more material. The results found that the informants could access the internet using JAWS and particular cellphones. Although the ability to operate tools is not as sophisticated as abled students, their searching skill is extraordinary. The informants' learning skills fit what they need. The informants' learning strategies mechanism includes receiving responses (listening or reading), storing responses (taking notes in Braille or recording with ICT instruments), and repeating them (reading/listening).

The informants knew well the learning resources needed for studying at home. They could also mention learning resources, such as lecturers, friends, library books, files, and the internet. For example, one informant mentioned Google as a specific word from the internet to search for news. These learning resources are vital as preliminary data tracing the informants' knowledge, which will be continued in procedural and conditional knowledge.

\section{Procedural Knowledge}

Procedural knowledge is knowledge of how the informants use learning strategies in declarative knowledge. Each informant further explained the learning strategies used (García-Ceberino., et.al., 2020) For the listening strategy from laptops with JAWS, six informants could explain how to use them and listen to the sound files. There were even three informants who demonstrated how to operate using the laptop/computer. Notes made in Braille could also be explained well. There was one informant who demonstrated. Even so, the researchers still found an informant who was not fluent in writing in Braille, so that he often did not take notes completely. However, the informant said that he would still use them to help him memorize.

The informants reminded the lecturers, friends, or volunteers to speak while they took notes slowly. In their opinion, lecturers with loud voices tended to scare and make them uncomfortable. To create a conducive lecture atmosphere is to involve all students and pay attention to conducive conditions (Zvoleyko, E. V., Kalashnikova, S. A., \& Klimenko, T. K. 2016). Understanding the students' conditions would create a pleasant atmosphere and boost the strategy's success level. The expected procedure is that the lecturers' and friends' explanation is delivered softly and clearly with average pace.

PSLD should conduct training or assistance in writing and speed reading in Braille. This knowledge and skills are crucial in note-taking activities to summarize the explanations and books read. So far, PSLD has assisted with using the JAWS Program, shown in the researchers' findings. The informants could optimally learn from the internet by reading files and utilizing cellphones as learning resources and media. 
Zamakhsari, Masruri \& Sutrisno | Self-Regulatory Learning Patterns of Disabled Students at UIN Sunan Kalijaga Yogyakarta

\section{Conditional Knowledge}

Conditional knowledge is the knowledge that informants have when strategies, skills, and resources are used, why they are used, what conditions are needed for them to take place, and the best steps if there are several procedures (Beierle, C., \& Haldimann, J. 2020). Accuracy in using knowledge will facilitate the process and accelerate and optimize the achievement of goals.

\section{Metacognitive Regulation}

Metacognitive knowledge is fundamental to know from the informants. With the ability to regulate metacognitive knowledge, other people will understand them better. Self-potential can be optimized and control activities to meet expectations with an awareness of one's abilities and shortcomings. This metacognitive regulation includes (1) planning, (2) information management strategy, and (3) integrated supervision (Fernandez-Duque., et.al, 2020; Teng, F., 2020). Planning means how the informants understand themselves in starting a task. The information management strategy is how the informants understand what is being learned or ensure that the assignment is appropriate. Integrated supervision is how informants learn to understand material easier.

\section{CONCLUSION}

Based on the result analysis, learning patterns based on students' self-regulation with visual disabilities of UIN Sunan Kalijaga Yogyakarta consist of metacognitive components, motivation, and learning strategies. The learning pattern based on self-regulation originates from a metacognitive component that creates motivation. Furthermore, this motivational component encourages students with visual disabilities to implement learning strategies at UIN Sunan Kalijaga.

The informants' metacognitive component showed good metacognitive knowledge and regulation. This informants' metacognitive contribution provided positive contributions and supportive directions for learning patterns based on students' self-regulation with visual impairments at UIN Sunan Kalijaga Yogyakarta. The self-regulation of informants in learning, formed from this metacognitive knowledge, was learning by relying on the sense of hearing. The strategies were based on listening, taking notes, and reading notes. Suitable learning skills included listening to information, taking notes in Braille, listening to information from files using the JAWS program appropriately, reading Braille books in the library, listening to recorded lectures with cellphones, and discussing with friends relying on memory. Learning sources for informants were lecturers, friends, library books, files, and the internet. The strategy of listening to information was immediately, and there were checks on various learning sources. 
Zamakhsari, Masruri \& Sutrisno | Self-Regulatory Learning Patterns of Disabled Students at UIN Sunan Kalijaga Yogyakarta

This study's findings can be used as input in developing a) The field of educational psychology in self-regulation learning theory for students with visual disabilities; b) Sensitive learning designs with visual impairments. It includes learning strategies and methods that prioritize group learning by discussing problems in which solutions can be applied in social and learning media based on audio media's use following the competence of information and communication technology literacy. Management design and services for students with visual impairments have orientations towards needs and providing the best service.

\section{REFERENCES}

Alfiana, Arini Dwi, “Regulasi Diri Mahasiswa Ditinjau dari Keikutsertaan dalam Organisasi Kemahasiswaan", Journal Ilmiah Psikologi Terapan, Fakultas Psikologi Universitas Muhammadiyah Malang, ISSN: 2301-8267 Vol. 01, No. 02, Agustus 2013.245-259. Bandung: Remadja Rosda Karya dan Unesa, 2011.

Andayani, A., \& Afandi, M. (2019). Pemberdayaan dan Pendampingan Komunitas Penyandang Disabilitas Dalam Mengakses Pendidikan Tinggi. Aplikasia: Jurnal Aplikasi Ilmu-ilmu Agama, 16(2), 153-166.

Azizah, N., \& Rahmatika, A. (2019). Korelasi Penggunaan Gadget Terhadap Kepuasan Komunikasi Interpersonal Pada Mahasiswa Disabilitas. alBalagh: Jurnal Dakwah dan Komunikasi, 3(2), 211-234.

Bandura, Albert, "Social Cognitive Theory of Self Regulation," Organizational Behavior and Human Decision Progresses, 50, 1991, hlm. 248-287

Bandura, Albert, Social Learning Theory, Englewood Cliffs: Prentice Hall Inc, 1977.

Baidarus, B., Hamami, T., Suud, F. M., \& Rahmatullah, A. S. (2020). Al-Islam dan kemuhammadiyahan sebagai basis pendidikan karakter. AL-ASASIYYA: Journal of Basic Education, 4(1), 71-91.

Basuki, U., \& Jaelani, A. Q. (2015). Kajian atas pelaksanaan pemenuhan hak pendidikan tinggi bagi penyandang difabilitas di UIN Sunan Kalijaga melalui pengesahan Convention on the Rights of Person with Disabilities sebagai upaya perlindungan hak asasi manusia dalam negara hukum Indonesia. Panggung Hukum Jurnal Perhimpunan Mahasiswa Hukum Indonesia Cabang Daerah Istimewa Yogyakarta, 1(2), 1-34. 
Zamakhsari, Masruri \& Sutrisno | Self-Regulatory Learning Patterns of Disabled Students at UIN Sunan Kalijaga Yogyakarta

Beierle, C., \& Haldimann, J. (2020, February). Normal Forms of Conditional Knowledge Bases Respecting Entailments and Renamings. In International Symposium on Foundations of Information and Knowledge Systems (pp. 22-41). Springer, Cham.

Berkeley, S., \& Larsen, A. (2018). Fostering Self-Regulation of Students with Learning Disabilities: Insights from 30 Years of Reading Comprehension Intervention Research. Learning Disabilities Research \& Practice, 33(2), 75-86.

Bogdan, C. Robert dan Sari Knopp Biklen, Qualitative Research for Education: An Introduction to Theory and Methods, Boston: Allyn and Bacon Inc, 1982.

Chung, Mi-Kyung, "The Development of Self-Regulated Learning," Asia Pacific Education Review 2000, Vol. 1, No. 1, The Institute of Asia Pacific Education Development.

Creswell, John W., Research Design: Pendekatan Kualitatif, Kuantitatif, dan Mixed,terj. Achmad Fawaid, Yogyakarta: Pustaka Pelajar, 2010.

Danim, Sudarwan dan Khoiril, Pedagogi, Andragogi, dan Heutagogi, Bandung: Alfabeta, 2010.

Di Blas, L., Grassi, M., Carnaghi, A., Ferrante, D., \& Calarco, D. (2017). Withinperson and between-people variability in personality dynamics: Knowledge structures, self-efficacy, pleasure appraisals, and the Big Five. Journal of Research in Personality, 70, 84-92.

Efendi, Mohamad, Pengantar Psikopedagogik Anak Berkelainan, Jakarta: Bumi Aksara, 2009.

Eka Mahendra, I. W. (2020). Developing character of disability students through picture and picture models with sad dharma method. International Journal of Psychosocial Rehabilitation, 24(6), 1711-1721.

Fadilah, R. (2020). Preschool Education: Knowledge or Social Skills, Journal Of Critical Reviews, 7 (17) (2020): 525-533

Fernandez-Duque, D., Baird, J. A., \& Posner, M. I. (2000). Awareness and metacognition.

Hanjarwati, A., \& Suprihatiningrum, J. (2020). Is Online Learning Accessible During COVID-19 Pandemic? Voices and Experiences of UIN Sunan Kalijaga Students with Disabilities. Nadwa, 14(1), 1-38.

Khaidir, E., \& Suud, F. M. (2020). Islamic Education in Forming 
Zamakhsari, Masruri \& Sutrisno | Self-Regulatory Learning Patterns of Disabled Students at UIN Sunan Kalijaga Yogyakarta

Students'characters at As-Shofa Islamic High School, Pekanbaru Riau. International Journal of Islamic Educational Psychology, 1(1), 50-63. 10.18196/ijiep.1105

Khafidah, W., Wildanizar, W., Tabrani, Z. A., Nurhayati, N., \& Raden, Z. (2020). The Application of Wahdah Method in Memorizing the Qur'an for Students of SMPN 1 Unggul Sukamakmur. International Journal of Islamic Educational Psychology, 1(1), 37-49. 10.18196/ijiep.1104

García-Ceberino, J. M., Gamero, M. G., Feu, S., \& Ibáñez, S. J. (2020). Experience as a Determinant of Declarative and Procedural Knowledge in School Football. International Journal of Environmental Research and Public Health, 17(3), 1063.

Muhadjir, Noeng, Metodologi Penelitian, Yogyakarta: Rake Sarasin, 2011.

Nurhayati, Eti, Psikologi Pendidikan Inovatif, Yogyakarta: Pustaka Pelajar, 2011.

Rinawati, R., Lestari, E. S., \& Narendra, A. P. (2017). Kepuasan Mahasiswa Tunanetra terhadap Layanan Difabel Corner di Perpustakaan UIN Sunan Kalijaga. INKLUSI Journal of Disability Studies, 4(2), 239-270.

Roberts, Thomas B., Four Psychologies Applied to Education: Freudian, Behavioral, Humanistic, Transpersonal, New York: Schenkman Pub. Co, 1975.

Salim, Agus, Teori dan Paradigma Penelitian Sosial, Edisi Kedua, Yogyakarta: Tiara Wacana, 2006.

Sari Nurulita, dkk., Jakarta: Gema Insani Press, 2006.

Slametto, Belajar dan Faktor-faktor yang Mempengaruhinya, Jakarta: Rineka Cipta, 1995.

Slavin, Robert E., Psikologi Pendidikan: Teori dan Praktek, Terj. Samosir M., (Ed).

Suyono dan Hariyanto, Belajar dan Pemblajaran: Teori dan Konsep Dasar

Suud, F. M., Sutrisno, S., \& Madjid, A. (2019). Educational Honesty: The Main Philosophical Value in School. TARBIYA: Journal of Education in Muslim Society, 6(2), 141-154.

Suud, F. M. (2018). Kepemimpinan Transformasional dan Implikasinya pada Pembentukan Budaya Jujur di Sekolah. Sukma: Jurnal Pendidikan, 2(2), 261286. 
Zamakhsari, Masruri \& Sutrisno | Self-Regulatory Learning Patterns of Disabled Students at UIN Sunan Kalijaga Yogyakarta

Taufiq, Muhammad Izzuddin, Panduan Lengkap dan Praktis Psikologi Islam, terj.

Tim Penyusun Kamus Pusat Pembinaan dan Pengambangan Bahasa, Kamus Besar Bahasa Indonesia,Jakarta: Balai Pustaka, 1989.

Teng, F. (2020). The role of metacognitive knowledge and regulation in mediating university EFL learners' writing performance. Innovation in Language Learning and Teaching, 14(5), 436-450.

Zimmerman, Barry J. "Becoming a Self-regulated Learner: An Overview."

Zvoleyko, E. V., Kalashnikova, S. A., \& Klimenko, T. K. (2016). Socialization of Students with Disabilities in an Inclusive Educational Environment. International Journal of Environmental and Science Education, 11(14), 6469-6481.

Wahyuna, A. H., \& Fitriana, S. (2020). The Concept of Hope in the Western and Eastern Perspective. International Journal of Islamic Educational Psychology, 1(1), 25-36. 10.18196/ijiep.1103 